\title{
Cereolysin: Production, Purification and Partial Characterization
}

\author{
By A. W. BERNHEIMER AND PHYLLIS GRUSHOFF \\ Department of Microbiology, New York University School of Medicine, \\ New York, New York, U.S.A. \\ (Accepted for publication 19 August 1966) \\ SUMMARY
}

\begin{abstract}
A method is described for production of the extracellular haemolytic growth-product of Bacillus cereus. The lytic substance, called 'cereolysin', can be purified by fractional precipitation with ammonium sulphate, densitygradient electrophoresis and gel filtration. The purified material is a labile protein of molecular weight about 52,000 . It has a very high order of haemolytic activity, is lethal for mice, and resembles streptolysin $\mathrm{O}$ in being inhibited by cholesterol, but differs from streptolysin $\mathrm{O}$ in other respects.
\end{abstract}

\section{INTRODUCTION}

Broth cultures of Bacillus cereus contain a powerful extracellular haemolysin which appears to have been little studied. We have investigated the nature and properties of this lytic product of bacterial growth in the belief that it might prove a useful reagent in studying the biochemistry of cell membranes. We were also curious to know whether the $B$. cereus lysin was related to other bacterial haemolysins which have been characterized, particularly those of Gram-positive cocci and clostridia.

\section{METHODS}

Organism. Bacillus cereus P2, a derivative of ATCC 12137, was kindly supplied by Professor M. R. J. Salton.

Measurement of haemolytic activity. The capacity of cereolysin to lyse washed rabbit red cells was measured as for staphylococcal alpha toxin (Bernheimer \& Schwartz, 1963), but with $0 \cdot 1 \%(\mathrm{w} / \mathrm{v})$ gelatin instead of bovine serum albumin. One unit of haemolysin is defined as the smallest amount which liberates half the haemoglobin in the test red cell suspension in $30 \mathrm{~min}$. at $37^{\circ}$.

Protein. Protein was estimated by reading extinction at $280 \mathrm{~m} \mu$ in a Zeiss PMQ II spectrophotometer with optical cells of $10 \mathrm{~mm}$. light path, and also by use of the Folin-Ciocalteu reagent (Colowick \& Kaplan, 1957).

Specific activity. The specific activity of cereolysin is expressed as units of haemolysin per unit extinction at $280 \mathrm{~m} \mu$.

Inhibition tests. The capacity of lipids to inhibit the haemolytic activity of cereolysin was assayed by mixing decreasing concentrations of test material with a fixed amount (3 haemolysin units) of cereolysin, allowing the mixtures ( $1 \mathrm{ml}$. each) to stand for $10 \mathrm{~min}$. at $20^{\circ}$, and adding $1 \mathrm{ml} .0 \cdot 7 \%$ (v/v) washed rabbit red cells. After $30 \mathrm{~min}$. at 
$37^{\circ}$ the mixtures were centrifuged briefly, and the haemoglobin in the supernatant fluids estimated colorimetrically at $545 \mathrm{~m} \mu$. The tests were done in the presence of M/13-NaCl, M/15-phosphate ( $\mathrm{pH} 7.0$ ) and $0.05 \%$ (w/v) gelatin; $50 \%$ haemolysis was used as the endpoint of the titrations. The same conditions were used to estimate the inhibitory capacity of sera except that complete inhibition of haemolysis was used as endpoint.

Reagents. Crystalline trypsin and papain were purchased from Worthington Biochemical Corp., Freehold, N.J.; crystalline chymotrypsin from Armour and Co., Chicago, Ill.; pronase (grade B) from Calbiochem, Los Angeles, Calif.; phosphatidylcholine and diphosphatidylglycerol from Sylvana Co., Millburn, N.J.; phosphatidylserine and sphingomyelin from Applied Science Laboratories, Inc., State College, Pa.; cholesterol from Matheson Coleman and Bell, East Rutherford, N.J.

Production of cereolysin. Preliminary experiments showed that in spite of heavy growth Bacillus cereus $\mathbf{P} 2$ produced very little cereolysin $(<100$ haemolysin units $/ \mathrm{ml}$.) when growing in chemically defined media, either the 16 amino acid medium of Proom \& Knight (1955) or medium 687 of Puziss \& Wright (1954). The same was true of a broth diffusate medium. In contrast, relatively high titres (500-3000 haemolysin units $/ \mathrm{ml}$.) were consistently obtained in meat-infusion peptone broth. To avoid using broth culture supernatant fluids as starting material for purification, and with the knowledge that substantial amounts of cereolysin were not formed during growth in defined media, the following technical compromise was evolved after much experimentation.

Each of eight 2-1. Erlenmeyer flasks, containing $300 \mathrm{ml} .1 \%$ (w/v) Neopeptone meat-infusion broth (Difco) per flask, was inoculated with 0.05-0.1 ml. broth culture of extinction $0 \cdot 1(650 \mathrm{~m} \mu)$, and incubated for $16-17 \mathrm{hr}$ at $37^{\circ}$ on a rotary shaker operating at $180 \mathrm{cyc} . / \mathrm{min}$. After centrifugation the culture supernatant fluids were discarded, the deposited bacilli washed in $1200 \mathrm{ml} .0 .025 \mathrm{M}$-phosphate (pH 6.0) and then suspended in $2400 \mathrm{ml}$. of solution containing $0.025 \mathrm{M}$-phosphate ( $\mathrm{pH} 6.0$ ), $1 \%(\mathrm{w} / \mathrm{v})$ ammonium sulphate, $0.33 \%(\mathrm{w} / \mathrm{v})$ glucose, and $17 \%(\mathrm{v} / \mathrm{v})$ meat infusion. The suspension was distributed among eight 2-1. Erlenmeyer flasks and returned to the $37^{\circ}$ rotary shaker for 3-5 hr. In these secondary cultures, very little growth occurred, less than a twofold increase in turbidity, but cereolysin appeared to the extent of 2500-5000 haemolysin units/ml., and occasionally more.

\section{RESULTS}

\section{Purification of cereolysin}

Cereolysin was routinely produced in the secondary cultures described in the preceding section. After centrifugation, the deposited bacilli were discarded and the supernatant fluid chilled, passed through a Millipore filter $(0.45 \mathrm{~m} \mu$ porosity) and the filtrate adjusted to $\mathrm{pH} 6.0$ with (about $10 \mathrm{ml}$.) $\mathrm{N}-\mathrm{NaOH}$ (stage 2, Table 1). All subsequent steps were done in the cold. The filtrate was approximately half-saturated with ammonium sulphate by dissolving in it $780-790 \mathrm{~g}$. of solid $\left(\mathrm{NH}_{4}\right)_{2} \mathrm{SO}_{4}$. After standing overnight the very small amount of precipitate that had formed was recovered by centrifugation at $13,000 \mathrm{rev} / \mathrm{min}$. for $30-45 \mathrm{~min}$. and was collected in $32 \mathrm{ml} .0 \cdot 4$ saturated ammonium sulphate (Table 1, stage 3).

The suspended precipitate was centrifuged at $13,000 \mathrm{rev}$./min. for $15 \mathrm{~min}$., the super- 
natant fluid discarded, and the residue dissolved in $2 \mathrm{ml} .5 \%$ (v/v) glycerol in 0.025 $\mathrm{M}$-phosphate, $(\mathrm{pH} 6)$. A small amount of insoluble material was removed by centrifugation and discarded (Table 1, stage 4).

The preparation was fractionated by electrophoresis in a linear density gradient $(0-50 \%, \mathrm{v} / \mathrm{v}$, glycerol) in $0.005 \mathrm{M}$-phosphate $(\mathrm{pH} 6.0)$, in the apparatus designed by Svensson (1960) and with the general conditions described earlier (Bernheimer, 1962). The distribution of material absorbing at $280 \mathrm{~m} \mu$ along the length of the column is shown in Fig. 1. All the recoverable haemolytic activity (50-80\% of the input activity) was present in the fractions comprising the narrow symmetrical peak. These fractions were pooled, and $4.5 \mathrm{~g}$. ammonium sulphate added, with stirring, to each $10 \mathrm{ml}$. After standing for $1 \mathrm{hr}$. the precipitate was collected by centrifugation and dissolved in $2 \mathrm{ml}$. $5 \%$ (v/v) glycerol in 0.025 M-phosphate ( $\mathrm{pH} \mathrm{6.0;} \mathrm{Table} \mathrm{1,} \mathrm{stage} \mathrm{5).}$

\begin{tabular}{|c|c|c|c|c|c|}
\hline Stage & & $\begin{array}{l}\text { Volume } \\
\text { (ml.) }\end{array}$ & $\begin{array}{l}\text { Total } \\
\text { haemolytic } \\
\text { activity } \\
\text { (units of } \\
\text { haemolysin) }\end{array}$ & $\begin{array}{c}\text { Specific } \\
\text { activity (units } \\
\text { of haemolysin } \\
\text { per unit } \\
\text { extinction } \\
\text { at } 280 \mathrm{~m} \mu \text { ) }\end{array}$ & $\begin{array}{l}\text { Recovery } \\
\text { of } \\
\text { activity } \\
(\%)\end{array}$ \\
\hline 1 & $\begin{array}{l}\text { 'Secondary' culture supernatant } \\
\text { fluid }\end{array}$ & 2320 & $10.5 \times 10^{6}$ & - & 100 \\
\hline 2 & Filtrate & 2290 & $10 \cdot 3 \times 10^{6}$ & 2,400 & 98 \\
\hline 3 & Ammonium sulphate precipitate & 32 & $7 \cdot 2 \times 10^{6}$ & 89,000 & 69 \\
\hline 4 & $\begin{array}{l}\text { Precipitate extracted with } 0.40 \\
\text { saturated ammonium sulphate, } \\
\text { dissolved in } 5 \% \text { glycerol in } 0.05 \\
\text { M-phosphate (pH 6); supernatant } \\
\text { fluid }\end{array}$ & 2 & $6 \cdot 1 \times 10^{6}$ & 220,000 & 58 \\
\hline 5 & $\begin{array}{l}\text { Pooled fractions from density- } \\
\text { gradient electrophoresis, pre- } \\
\text { cipitated with ammonium sulphate } \\
\text { and dissolved in } 5 \% \text { glycerol } \\
\text { at pH } 6\end{array}$ & 2 & $4.8 \times 10^{6}$ & $1,500,000$ & 46 \\
\hline 6 & $\begin{array}{l}\text { Pooled active factcions of } \\
\text { Sephadex G-100 effluent, pre- } \\
\text { cipitated with ammonium sulphate } \\
\text { and dissolved in } 5 \% \text { glycerol at } \\
\text { pH } 6\end{array}$ & $2 \cdot 3$ & $2.8 \times 10^{6}$ & $1,900,000$ & 27 \\
\hline
\end{tabular}

The sedimentation coefficient of stage 5 (Table 1) cereolysin was estimated by the method of Martin \& Ames (1961) by using a 5-25\% (v/v) linear glycerol gradient with crystalline bovine serum albumin and crystalline beef liver catalase as standards. From the position of the peak of activity of cereolysin an $S_{20, \mathrm{w}}$ of 3.7 was obtained; from this value the molecular weight of cereolysin was estimated to be about 49,000 .

In density gradient electrophoresis, haemolytic activity in the narrow symmetrical peak (Fig. 1) was never congruent with the $280 \mathrm{~m} \mu$ absorption curve but always fell along the right limb of the absorption peak while little or no activity was found on the left side. It follows that the sharp peak was not homogeneous; this conclusion was supported $(a)$ by the results of acrylamide gel electrophoresis (analytical disc method) which revealed two major amido-black staining components, $(b)$ by the schlieren patterns obtained in the analytical ultracentrifuge in which the material had resolved into two rather polydisperse components having approximate $S_{20, \text { w }}$ values of 3.4 and 
$1 \cdot 8$. The former value is in reasonably good agreement with that obtained by density gradient centrifugation, and it may be presumed to represent the active material.

Stage 5 (Table 1) material was further purified either by recycling in the density gradient electrophoresis apparatus or by filtration through cross-linked dextran beads (Sephadex G-100). Both procedures yielded preparations having the same, very high, specific activity $\left(1.9 \times 10^{6}\right.$ haemolysin units per unit of $280 \mathrm{~m} \mu$ extinction) and the product is considered to be cereolysin in a substantially pure state. The data of Table 1 represent the best of a considerable number of purifications, in some of which the recovery of activity was lower than that shown.

\section{Nature and properties of cereolysin}

Cereolysin is a highly unstable substance. The half-life of haemolytic activity of fresh culture supernatant fluid was $1-3 \mathrm{~min}$. at $50^{\circ}, 45 \mathrm{~min}$. at $40^{\circ}$ and $1-3$ days at $5^{\circ}$. It was labile over a wide range of $\mathrm{pH}$ values but lost activity less rapidly between

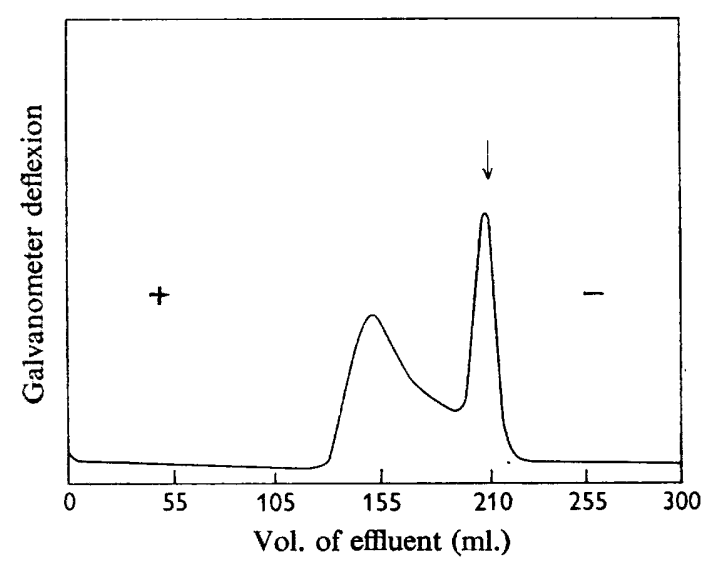

Fig. 1

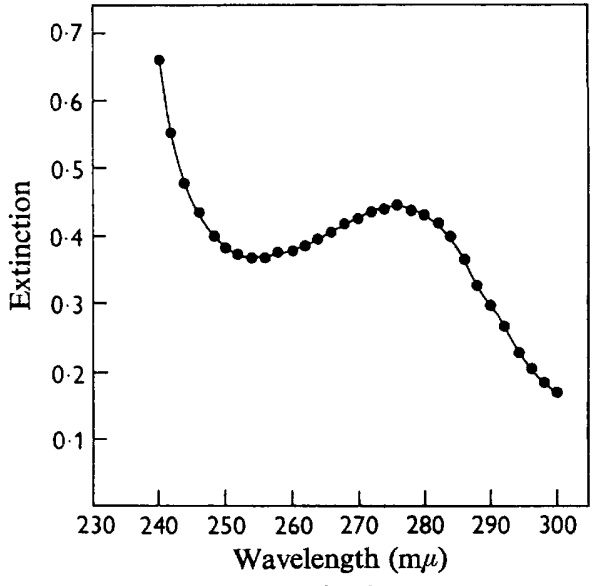

Fig. 2

Fig. 1. Ultraviolet absorption of column effluent after electrophoresis of stage 4 cereolysin (Table 1) in glycerol density gradient for $21 \mathrm{hr}$. at $400 \mathrm{~V}$ and $4 \mathrm{~mA}$. Arrow indicates position of starting zone.

Fig. 2. Ultraviolet absorption spectrum of stage 6 cereolysin (Table 1).

pH 5.0 and 7.0 than outside this range. It was not stabilized by ethylenediamine tetraacetate, cysteine or mercaptoethanol, nor could it be freeze-dried without loss of activity. However, in the presence of $5-20 \%(\mathrm{v} / \mathrm{v})$ glycerol in phosphate buffer $(\mathrm{pH} 6.0)$ solutions maintained full activity for at least several days at $5^{\circ}$ and for at least several weeks when they were slow-frozen and stored at $-20^{\circ}$. For these reasons, cereolysin was handled and stored in the presence of glycerol (usually $5 \%, \mathrm{v} / \mathrm{v}$ ), whenever practical.

The ultraviolet absorption spectrum of the purified haemolysin is typical of a protein (Fig. 2). The ratio of extinction at $280 \mathrm{~m} \mu$ to protein, as estimated by phenol colour (Colowick \& Kaplan, 1957) with crystalline bovine serum albumin as standard, was 1.8 extinction units $/ \mathrm{mg}$. protein. In spite of its lability, cereolysin was inactivated little or not at all by trypsin, chymotrypsin or papain, but appreciable loss of activity accompanied treatment with pronase (Table 2). 
The molecular weight of cereolysin was estimated by gel-filtration according to the method of Andrews (1964) by using Sephadex G-100 (superfine) in a $9 \times 405 \mathrm{~mm}$. water-jacketed column, with bovine serum albumin and soy trypsin inhibitor as standards. The standard proteins were estimated in the effluent spectrophotometrically while cereolysin was estimated spectrophotometrically and by haemolytic assay. The results are shown in Table 3, which includes for comparison the molecular weights,

Table 2. Effect of proteolytic enzymes on cereolysin activity

\begin{tabular}{|c|c|}
\hline $\begin{array}{l}\text { Approximately } 10,000 \text { haemolysin units } \\
\text { of cereolysin in } 0.9 \mathrm{ml} .0 .025 \mathrm{M} \text {-phosphate } \\
\text { (pH 6) containing } 0.5 \%(\mathrm{v} / \mathrm{v}) \text { glycerol, plus }\end{array}$ & $\begin{array}{l}\text { Percentage of control } \\
\text { haemolytic activity } \\
\text { after } 30 \mathrm{~min} \text {. at } 20^{\circ}\end{array}$ \\
\hline $0.1 \mathrm{ml} .0 .025 \mathrm{M}$-phosphate (pH 6) & 100 \\
\hline $10 \mu \mathrm{g}$. crystalline trypsin & 100 \\
\hline $100 \mu \mathrm{g}$. crystalline chymotrypsin & 74 \\
\hline $100 \mu \mathrm{g}$. crystalline papain in $0 \cdot 1 \%(\mathrm{w} / \mathrm{v})$ cysteine & 100 \\
\hline $100 \mu$ g. pronase & 20 \\
\hline $10 \mu \mathrm{g}$. pronase & 35 \\
\hline
\end{tabular}

Table 3. Estimations of molecular weight of various haemolysins!by gel-filtration

$\begin{array}{lcc}\text { Cereolysin } & \begin{array}{c}\text { Molecular } \\ \text { weight found }\end{array} & \begin{array}{c}\text { Property measured in } \\ \text { order to localize peak }\end{array} \\ \text { Staphylococcal } \alpha \text {-toxin } & 54,000 & \text { haemolytic activity } \\ \text { Phospholipase C (Clostridium welchii) } & 41,000 & 280 \mathrm{~m} \mu \text { absorption } \\ \text { egg-yolk turbidity }\end{array}$

Table 4. Lethality of cereolysin to mice

$\begin{array}{ccc}\begin{array}{c}\text { Amount of cereolysin } \\ \text { injected } \\ \text { (units haemolysin) }\end{array} & \begin{array}{c}\text { Number of mice dead } \\ \text { Number of mice injected }\end{array} & \begin{array}{c}\text { Survival time } \\ \text { of mice dying } \\ \text { (min.) }\end{array} \\ 10,000 & 3 / 4 & 2 \text { to } 7 \\ 5,000 & 4 / 4 & 17 \text { to } 25 \\ 2,500 & 1 / 4 & 52 \\ 1,250 & 0 / 4 & - \\ \text { None* } & 0 / 4 & - \\ & \text { * Diluent control. }\end{array}$

obtained by the same means, of two other haemolytic proteins. The agreement between the values for cereolysin of 54,000 by gel-filtration and 49,000 calculated from the sedimentation coefficient are well within the experimental error of the methods.

A sample of stage 6 cereolysin, estimated from its $280 \mathrm{~m} \mu$ absorbance to contain $0.52 \mathrm{mg}$. protein, was dialysed against distilled water and analysed for amino acids by the method of Piez \& Morris (1960) with the following results, expressed as g. amino acid residue $/ 100 \mathrm{~g}$. protein: cysteic acid $2 \cdot 15$; aspartic acid $12 \cdot 65$; threonine $4 \cdot 78$; serine 4.43 ; glutamic acid 10.2 ; proline 8.42 ; glycine $9 \cdot 7$; alanine 5.08 ; valine 4.47 ; half-cystine 0.31 ; methionine 1.38 ; isoleucine 3.74 ; leucine 4.47 ; tyrosine 3.12 ; phenylalanine 3.01 ; ammonia 1.30 ; lysine 5.73 ; histidine 1.55 ; arginine 3.48 ; hydroxyproline $9 \cdot 10$; glucosamine (?) tr; hydroxylysine $0 \cdot 73$; ornithine (?) $0 \cdot 20$. The total weight of amino acids detected in the chromatogram was $0.414 \mathrm{mg}$. 
Lethality. Swiss mice of the Webster strain weighing about $25 \mathrm{~g}$. were injected intravenously with $0.1 \mathrm{ml}$. stage 5 cereolysin diluted in $0.9 \%(\mathrm{w} / \mathrm{v}) \mathrm{NaCl}$ containing $0.1 \%$ $(w / v)$ gelatin. The results (Table 4) showed that about 5000 haemolysin units, or 1-2 $\mu$ g. toxic protein, constituted a mouse lethal dose. The mice appeared to die of respiratory difficulty and their response to cereolysin resembled that occuring in mice injected with streptolysin $\mathrm{O}$.

Inhibition by serum. The capacity of human sera to inhibit cereolysin haemolysis of rabbit red cells is shown in Table 5. Different serum specimens inhibited to different degrees, and no correlation with capacity to inhibit streptolysin $\mathrm{O}$ was evident.

Inhibition by lipids. Several lipids were tested for capacity to inhibit cereolysin haemolysis. Only cholesterol inhibited in low concentration (Table 6).

Table 5. Inhibition of cereolysin haemolysis of rabbit red cells by human sera

$\begin{array}{ccc}\text { Serum } & \begin{array}{c}\text { Highest dilution of } \\ \text { serum completely } \\ \text { inhibiting cereolysin } \\ \text { haemolysis }\end{array} & \begin{array}{c}\text { Highest dilution of } \\ \text { serum completely } \\ \text { inhibiting } \\ \text { streptolysin } \\ \text { (Todd units) }\end{array} \\ \text { E } & <15 & 12 \\ \text { F } & 15 & 125 \\ \text { W } & 250 & 250 \\ \text { A } & <15 & 625 \\ \text { G } & 80 & 1250\end{array}$

Table 6. Effect of lipids on cereolysin haemolysis of rabbit red cells

\begin{tabular}{lc}
\multicolumn{1}{c}{ Lipid } & $\begin{array}{r}\text { Concentration required to } \\
\text { inhibit } 2 / 3 \text { of test-amount } \\
\text { of cereolysin }(\mu \mathrm{g} . / \mathrm{ml} .)\end{array}$ \\
Phosphatidylcholine (egg) & $>500$ \\
Phosphatidylcholine (beef) & 100 \\
Phosphatidylserine (brain) & 250 \\
Diphosphatidylglycerol (beef) & $>250$ \\
Sphingomyelin (brain) & $>500$ \\
Cholesterol & 10
\end{tabular}

\section{DISCUSSION}

The results show that the cereolysin produced by Bacillus cereus $\mathrm{P} 2$ is one of the most potent in vitro haemolytic agents. In purified form and under the conditions described it causes gross lysis of test red cells in a concentration of about $1 \mu \mu \mathrm{g} . / \mathrm{ml}$. Other haemolytic agents known to have a comparable potency are streptolysin $\mathrm{S}$ with a specific activity calculated to be $2 \times 10^{6}$ haemolysin units $/ \mathrm{mg}$. dry weight (Koyama \& Egami, 1963) and staphylococcal $\beta$-toxin having a specific activity of $1.2 \times 10^{6}$ haemolysin units/mg. protein (Wiseman, 1965). The latter lysin has been shown (Doery, Magnusson, Gulasekharam \& Pearson, 1965) to be a phospholipase C with a preference for sphingomyelin and lysophosphatidylcholine. During the present work we have been aware of the possibility that cereolysin might be a similar enzyme, but purified cereolysin produced no turbidity in diluted egg yolk and therefore appears to be completely free from phospholipase $\mathrm{C}$ activity. This finding is in agreement with those of Johnson \& Bonventre (1966) who reported that $B$. cereus phospholipase C is neither haemolytic nor lethal. 
The general behaviour of cereolysin indicates that it is a protein, and the results of ult racentrifugal and gel-filtration experiments show that its molecular weight is close to 50,000 . However, the presence in our most active material of $9 \cdot 1 \%$ hydroxyproline, as well as a little hydroxylysine, is an unexpected finding, and implies either (a) that cereolysin is a protein of unusual amino acid composition somewhat resembling that of collagen, or $(b)$ that our most active preparation is still grossly impure and consists largely of gelatin-like material derived from meat infusion present in the medium in which the cereolysin was originally produced. If conditions can be found for preparing cereolysin in adequate amounts in the absence of meat infusion, it should be possible to decide which explanation is correct.

Cereolysin is similar to streptolysin $\mathrm{O}$ in being inhibited by cholesterol in low concentration, in giving rise to 'rapid' haemolysis (as distinct from lysis preceded by an induction period of the kind seen with streptolysin S, for example), and in its effects on mice; its mode of action probably resembles very closely that of streptolysin $O$. Nevertheless it differs from streptolysin $O$ in not being activated by cysteine and other sulphydryl compounds. Although human sera inhibited cereolysin-induced haemolysis to various degrees, there was no correlation between the cereolysin-inhibiting and the streptolysin O-inhibiting capacities of the sera, and therefore there is no suggestion of an immunological relationship between the two lytic agents.

The function that cereolysin may fulfil for the organism which produces it is almost wholly obscure, but as much can be said for many other extracellular products of microbial growth. A clue might perhaps be provided by an understanding of the determinants of its production.

The authors acknowledge with thanks the help of Dr S. W. Tanenbaum and Dr E. Bassett who made the amino acid analysis, and that of Dr R. C. Warner and Mr F. Zaboretsky for an analysis in the model E Spinco ultracentrifuge. This work was supported in part by a grant (AI-02874-07) from the National Institute of Allergy and Infectious Diseases of the U.S. Public Health Service, by a grant from the Life Insurance Medical Research Fund, and by Public Health Service Research Career Program Award 5K6-AI-14, 198-05.

\section{REFERENCES}

ANDREws, P. (1964). Estimation of the molecular weights of proteins by Sephadex gel-filtration. Biochem J. 91, 222.

BERNHEIMER, A. W. (1962). Resolution of mixtures of proteins by means of zone electrophoresis in sucrose density gradients. Archs. Biochem. Biophys. 96, 226.

BERNHEIMER, A. W. \& SCHWARTZ, L. L. (1963). Isolation and composition of staphylococcal alpha toxin. J. gen. Microbiol. 30, 455 .

Colowick, S. P. \& Kaplan, N. O. (1957). Protein estimation with the Folin-Ciocalteu reagent. Meth. Enzymol. 3, 448.

Doery, H. M., Magnusson, B. J., Gulasekharam, J. \& Pearson, J. (1965). The properties of phospholipase enzymes in staphylococcal toxins. J. gen. Microbiol. 40, 283.

JoHnson, C. E. \& BonvenTRe, P. F. (1966). Studies on the lethal toxin of Bacillus cereus. Bact. Proc. p. 41.

KoYAMA, J. \& Egami, F. (1963). Biochemical studies on streptolysin $S^{\prime}$ formed in the presence of yeast ribonucleic acid. I. The purification and some properties of the toxin. J. Biochem. 53, 147.

MARTIN, R. G. \& AMEs, B. N. (1961). A method for determining the sedimentation behavior of enzymes: application to protein mixtures. J. biol. Chem. 236, 1372. 
PIEZ, K. A. \& Morrus, L. (1960). A modified procedure for the automatic analysis of amino acids. Analyt. Biochem. 1, 137.

Proom, H. \& KNIGHT, B. C. J. G. (1955). The minimal nutritional requirements of some species in the genus Bacillus. J. gen. Microbiol. 13, 474.

PUZISs, M. \& WRIGHT, G. G. (1954). Studies on immunity in anthrax. IV. Factors influencing elaboration of the protective antigen of Bacillus anthracis in chemically defined media. J. Bact. 68, 474.

Svensson, H. (1960). In A Laboratory Manual of Analytical Methods in Protein Chemistry Including Polypeptides, Ed. by P. Alexander and R. J. Block, vol. 1, p. 193. London: Pergamon Press.

WiSEmAN, G. M. (1965). Some characteristics of the beta haemolysin of Staphylococcus aureus. $J$. Path. Bact. 89, 187. 